\title{
Calvarial doughnut lesions-bone fragility syndrome
}

INSERM

\section{Source}

INSERM. (1999). Orphanet: an online rare disease and orphan drug data base. Calvarial doughnut lesions-bone fragility syndrome. ORPHA:85192

This syndrome is characterised by multiple doughnut-shaped hyperostotic or osteosclerotic lesions of the calvaria. 